\title{
Triple balloon enteroscopy: a combined method
}

Double-balloon enteroscopy (DBE) has high diagnostic and therapeutic yield $(70 \%-85 \%)$ [1], but low completion rates $(18 \%-66 \%)[2,3]$. The NaviAid device (SMART Medical Systems Ltd., Ra'anana, Israel) consists in a throughthe-scope (TTS) balloon for deep enteroscopy using a colonoscope [4]. In this case, we combined both types of enteroscopy to achieve deeper insertion.

A 52-year-old man was admitted for melena with negative gastroscopy and colonoscopy. Capsule endoscopy showed angioectasia in the jejunum and ileum ( Fig. 1).

Before the enteroscopy began, the TTS balloon (NaviAid $A B$ ) was introduced through the 3.2-mm working channel of an EN-580 T double-balloon enteroscope (Fujinon Inc., Japan). An oral DBE was performed advancing $3.5 \mathrm{~m}$ from the ligament of Treitz. After five ineffective progression attempts, the TTS balloon was pushed forward $20-30 \mathrm{~cm}$ out of the enteroscope. The TTS balloon was inflated and anchored in the small bowel. The enteroscope balloon was deflated and the enteroscope was pushed as far as the TTS balloon, before the enteroscope balloon was again inflated. The overtube balloon was then deflated and the overtube was pushed to the distal section of the enteroscope. Once the three inflated balloons were together, they were pulled back under fluoroscopic guidance. The same steps were performed repeatedly, achieving a further advance of $1.5 \mathrm{~m}$ ( $\vee$ Video 1$)$. During the retrieval, angioectasias were treated with argon plasma coagulation.

Endoscopy_UCTN_Code_TTT_1AP

Competing interests

None
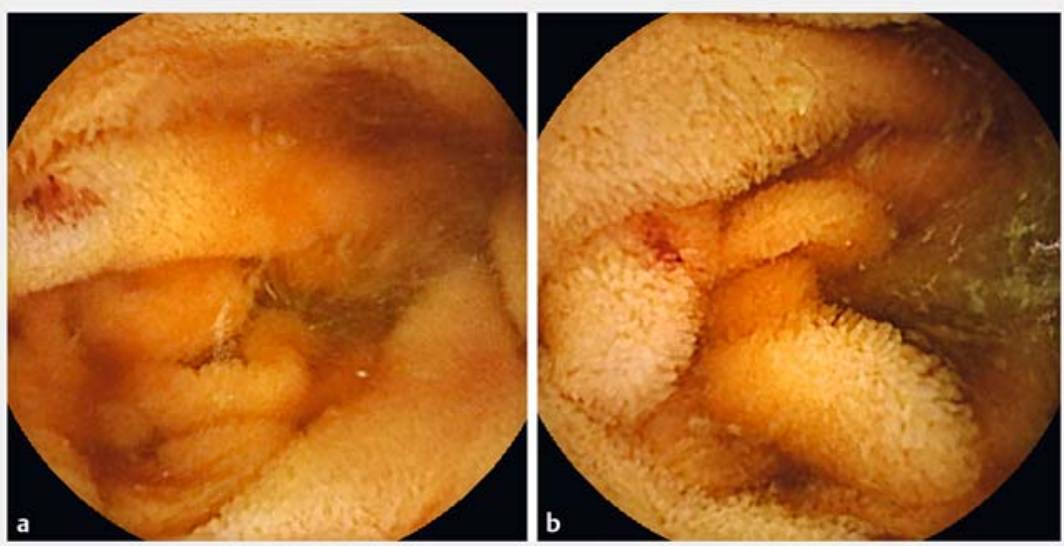

- Fig. 1 Capsule endoscopy images showing angioectasias in the small bowel.

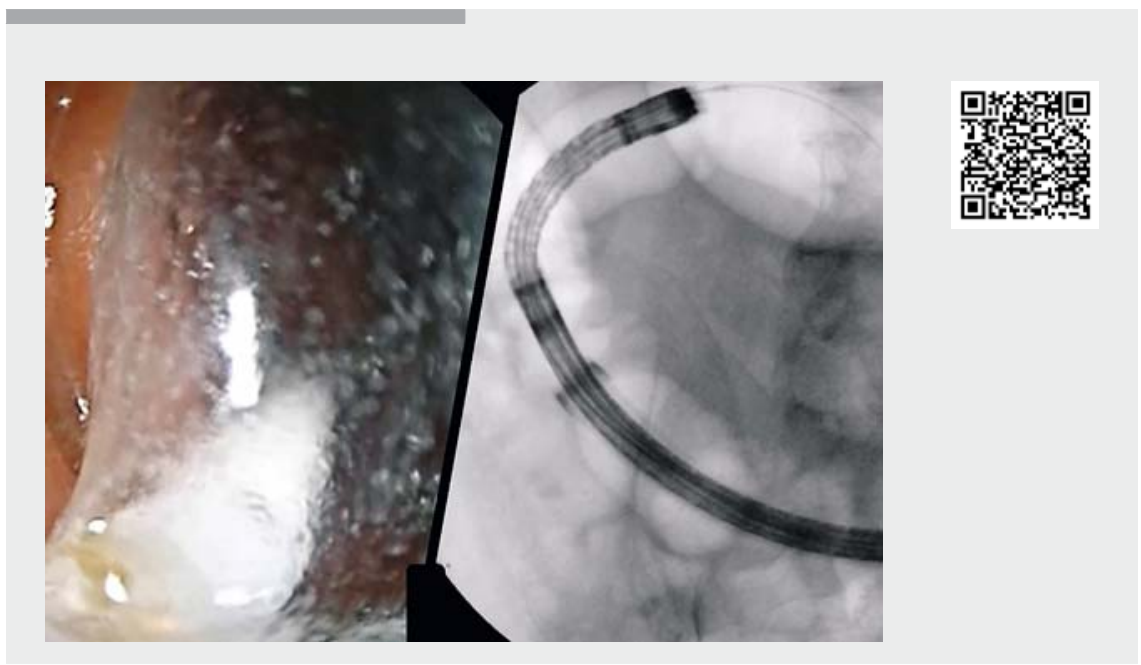

$\checkmark$ Video 1 Schematic showing the technique of triple-balloon enteroscopy, along with views during the procedure which allowed for improved advancement of the enteroscope through the small bowel.

The authors

\section{Gerardo Blanco-Velasco, Raúl Antonio} Zamarripa-Mottu, Omar Michel SolórzanoPineda, Oscar Víctor Hernández-Mondragón, Juan Manuel Blancas-Valencia

Department of Endoscopy, Hospital de Especialidades, Centro Médico Nacional Siglo XXI, Instituto Mexicano del Seguro Social, Mexico City, Mexico
Corresponding author

\section{Gerardo Blanco-Velasco, MD}

Department of Endoscopy, Hospital de Especialidades, Centro Médico Nacional Siglo XXI, Instituto Mexicano del Seguro Social, Av. Cuauhtémoc 330, Mexico City, 06725, Mexico

Fax: +52-55-740535

gerardoblancov@hotmail.com 


\section{References}

[1] May A. Double-balloon enteroscopy. Gastrointest Endoscopy Clin N Am 2017; 27: $113-122$

[2] Domagk D, Mensink P, Aktas H et al. Single vs. double-balloon enteroscopy in smallbowel diagnostics: a randomized multicenter trial. Endoscopy 2011; 43: 472-476

[3] May A, Farber M, Aschmoneit I et al. Prospective multicenter trial comparing pushand-pull enteroscopy with the single- and double-balloon techniques in patients with small-bowel disorders. Am J Gastroenterol 2010; 105: 575-581
[4] Ali R, Wild D, Shieh F et al. Deep enteroscopy with a conventional colonoscope: initial multicenter study by using a through-thescope balloon catheter system. Gastrointest Endosc 2015; 82: 855-860

\section{Bibliography}

DOI https://doi.org/10.1055/a-0966-8431

Published online: 24.7.2019

Endoscopy 2019; 51: E390-E391

(c) Georg Thieme Verlag KG

Stuttgart · New York

ISSN 0013-726X

\section{ENDOSCOPY E-VIDEOS}

https://eref.thieme.de/e-videos

口回 Endoscopy E-Videos is a free access online section, reporting 靣: on interesting cases and new techniques in gastroenterological endoscopy. All papers include a high quality video and all contributions are freely accessible online.

This section has its own submission website at

https://mc.manuscriptcentral.com/e-videos 